\title{
PLENARY SESSION
}

\section{Well Done is Better than Well Said}

\section{Benjamin Franklin as a DEIA Model for Higher Education}

Alexia Hudson-Ward, Massachusetts Institute of Technology (MIT) Libraries

\begin{abstract}
Heralding Benjamin Franklin as a model for diversity, equity, inclusion, and accessibility (DEIA) can be viewed as peculiar as it sounds. Without question, Franklin's personal and professional histories as a past slaveholder, alleged womanizer, and bully are problematic. Yet, the messiness of Franklin's life with all of its inherent complications and his transformation into a champion for the oppressed makes him a ripe subject for ongoing study. Moreover, Franklin's life example can help us formulate a roadmap for how we too can evolve and transform in our thinking, allyship, and approaches to diversity, equity, inclusion, and accessibility.
\end{abstract}

\section{AN OVERVIEW OF BENJAMIN FRANKLIN'S LIFE}

Benjamin Franklin was an inventor, scientist, diplomat, writer, and publisher. Considered one of America's founding fathers, Franklin was also a leader in the American Enlightenment movement. He is credited for inventing several items that remain in use in the 21st century, such as the lightning rod and bifocals. Born in Boston in January of 1706 (the actual birth date is disputed), Franklin moved to Philadelphia at age 17. He engineered career, creativity, and activism ambitions to crystalize a vision of a unified America to be shaped from the loosely connected colonies. 
Franklin rallied support domestically and internationally in support of America during the Revolutionary War. He published a series of newspapers and pamphlets that espoused principles of self-governing institutions, education, the value of community, and thriftiness. His imprints are on entities of broad impact. This impact includes the following: an appointment as the first Postmaster General of the United States Postal Service, creating the University of Pennsylvania (where he served as its first president), the Library Company of Philadelphia, and the American Philosophical Society (creating both entities and serving as the American Philosophical Society's president).

For all of his accomplishments, Franklin remains a problematic historical figure. He enslaved Africans and made horrendous quotes of Black people such as "sullen, malicious, revengeful" and "by nature [thieves]." Franklin is alleged to have been a prolific bully. His relationship with his common-law wife of forty years (Deborah Read) was compromised by rumors of infidelity and a child conceived with another woman that he brought home for Deborah to raise.

Despite his personality flaws and massive celebrity and wealth, Franklin did the unthinkable for white men of his era. He changed his opinion on the condition of enslaved Africans in America and became an abolitionist. Franklin worked to rally support for the education of free and enslaved Black people (Isaacson 2004; Brands 2010).

\section{FOREGROUNDING FRANKLIN'S QUOTE TO CREATE THE “FRANK- LIN MODEL OF DEIA"}

Benjamin Franklin was a man of many profound quotes, of which several have a timeless quality of applicability for the modern era. Among Franklin's most-cited quotes is “Well done is better than well said." (Franklin 1737). It is this quote that can foreground a Franklincentered DEIA framework within any organization.

A reliance on noble rhetoric and opaque organizational objectives that fail to gain traction tends to be commonplace with DEIA initiatives. Too often, the research indicates that many individuals verbalize the will to engage in meaningful DEIA work (Leslie et al. 2021) yet fail to operationalize DEIA efforts beyond celebrating (often dead) heroes and holidays (Gilbert 2016). The work of DEIA must not stop with verbal expressions. 
While articulating the importance of DEIA within one's workplace is central to its success, implementation and embedding sustainable practices matter more. However, producing meaningful DEIArelated organizational practices requires solid strategic and tactical deployment, as there are more examples of failures than successes in operationalizing DEIA (Dobbin and Kalev 2016). Moreover, the emotional and cultural stakes are higher for DEIA more than ever before as the nation reckons with inequality and racial justice amid the COVID-19 pandemic.

The enormity of the times can weigh heavily on leaders and those seeking to support organizational change. Consequently, many people seek role models or best practices that are relatable and tangible. In recognition of the role-modeling phenomena, the Franklin Model of DEIA is proposed to be leveraged within any organization. There are six insights from Franklin's life that informed the Franklin Model of DEIA - a model first presented at the 2021 Atla Annual conference.

- Franklin's problematic history with race, including being a slaveholder and later transforming into an abolitionist

- His role as a polymath

- Democratizing access to information

- Elevating the importance of global connections

- Commitment to the experimentation-to-insights-to-action cycle

- Creation of sustaining practices, processes, and entities

Outlining Franklin's accomplishments in this fashion draws together the red thread of connectivity that spurred the creation of the Franklin Model of DEIA. Franklin demonstrated how one must not become paralyzed in guilt over past behaviors to the point that it disables actions and personal course correction. His broad interest drew him to a series of simultaneous intellectual pursuits and heralded the need to undergo study before implementing any major initiatives.

Franklin created multiple publications and mechanisms to distribute information and knowledge to the masses. His bridge-building relationship with France translated into resources in support of the nation during its first major war. Franklin believed in the power of experimentation and leveraging insights towards action. Lastly, he created scores of permanent organizations to carry forward his educational and community-building principles. 


\section{CONCLUSION}

Moving past noble rhetoric to advance DEIA initiatives requires introspection among everyone within an organization before shifting into implementation mode. It is critical to note that the incremental pace of change in organizations is often slow and frustrating. To effect actual organizational change, white colleagues must acknowledge past DEIA-related transgressions, share what was learned from those experiences, and demonstrate an openness to move forward. People of color must allow white colleagues to work through their cycle of self-actualization of potential DEIA-related shortcomings in their own time while also pressing them to move beyond introspection to action.

We are at a precipice moment in the world's history with equality and social justice. We must quickly shift from task-saturation orientation to achievement orientation for DEIA initiatives. The hard work of DEIA begins with coming from a place of mutual understanding that starts with honest dialogue. The Franklin Model of DEIA provides one framework to begin these critical conversations.

\section{BIBLIOGRAPHY}

Brands, Henry William. 2010. The First American: The Life and Times of Benjamin Franklin. New York: Anchor.

Dobbin, Frank, and Alexandra Kalev. 2016. "Why Diversity Programs Fail.” Harvard Business Review 94, no. 7: 52-60.

Franklin, Benjamin. 1737. Poor Richard's Almanack.

Gilbert, Julie. 2016. "Heroes and Holidays: The Status of Diversity Initiatives at Liberal Arts College Libraries.” College \& Research Libraries 77, no. 4: 520-535.

Isaacson, Walter. 2004. Benjamin Franklin: An American Life. New York: Simon \& Schuster.

Leslie, Lisa Michelle, Elinor Flynn, Olivia Foster-Gimbel, and Colleen Flaherty Manchester. 2021. "Happy Talk: Is Common Diversity Rhetoric Effective Diversity Rhetoric?” In Academy of Management Proceedings, vol. 2021, no. 1, p. 10174. Academy of Management. 